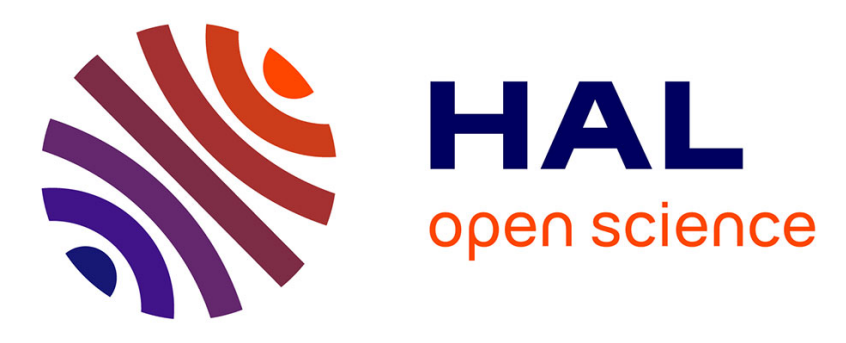

\title{
Synthesis, molecular structure analyses and DFT studies on new asymmetrical azines based Schiff bases
}

\author{
M. Yahyaoui, A. Bouchama, B. Anak, C. Chiter, A. Djedouani, Franck
}

Rabilloud

\section{- To cite this version:}

M. Yahyaoui, A. Bouchama, B. Anak, C. Chiter, A. Djedouani, et al.. Synthesis, molecular structure analyses and DFT studies on new asymmetrical azines based Schiff bases. Journal of Molecular Structure, 2019, 1177, pp.69-77. 10.1016/j.molstruc.2018.09.039 . hal-02285874

\section{HAL Id: hal-02285874 \\ https://univ-lyon1.hal.science/hal-02285874}

Submitted on 12 Mar 2021

HAL is a multi-disciplinary open access archive for the deposit and dissemination of scientific research documents, whether they are published or not. The documents may come from teaching and research institutions in France or abroad, or from public or private research centers.
L'archive ouverte pluridisciplinaire HAL, est destinée au dépôt et à la diffusion de documents scientifiques de niveau recherche, publiés ou non, émanant des établissements d'enseignement et de recherche français ou étrangers, des laboratoires publics ou privés. 


\title{
Synthesis, molecular structure analyses and DFT studies on new asymmetrical azines based Schiff bases
}

\author{
Messaoud Yahyaoui ${ }^{1}$, Abdelaziz Bouchama ${ }^{2}$, Barkahem Anak ${ }^{3,4}$, Chaabane Chiter ${ }^{1}$, Amel \\ Djedouani $^{3,5, *}$, Franck Rabilloud ${ }^{6, *}$ \\ ${ }^{1}$ Laboratoire d'Electrochimie des Matériaux Moléculaires et Complexes, Université Ferhat Abbas Sétif 1, \\ Sétif 19000, Algérie, \\ ${ }^{2}$ Laboratoire de Chimie, Ingénierie Moléculaire et Nanostructures, Université Ferhat Abbas Sétif 1, Sétif \\ 19000, Algérie, \\ ${ }^{3}$ Ecole normale supérieure de Constantine, ville universitaire Constantine 3, 25000, Algérie. \\ ${ }^{4}$ Laboratoire de Chimie des Matériaux, université de Constantine 1, 2500, Algérie ${ }^{5}$ Laboratoire de \\ Physicochimie Analytique et Cristallochimie des Matériaux Organométalliques et \\ Biomoléculaires, université Constantine 1, route Ain el bay 25000 , Algérie. \\ ${ }^{6}$ Univ Lyon, Université Claude Bernard Lyon 1, CNRS, Institut Lumière Matière, F-69622, Villeurbanne, \\ France \\ "Corresponding authors
}

\begin{abstract}
In this paper, we report the synthesis of new unsymmetrical azines Schiff bases. These compounds were prepared by condensation of hydrazine with different aldehydes and ketones to give (E) -2-hydroxynaphthalene-1-carbaldehyde [(1E) -2-thienylmethylene] hydrazone compound (I) and (Z) - 2 - [(E) -1- (2-hydroxyphenyl) ethylidenehydrazin-1-ylidene] -1,2diphenylethanone compound (II). The method adopted consists in reacting the two different carbonyl compounds simultaneously in one step in a stepwise manner reported which is practical and cost-effective. The reaction with a minor modification in operating conditions proceeded efficiently and with excellent performance. The structure of each of the two compounds (I) and (II) was determined by the X-ray diffraction technique performed on single crystals. The asymmetric unity of the two molecules consists of one asymmetry-independent molecule. In addition, hydrogen bonds $\mathrm{C}-\mathrm{H} \ldots \pi$ are observed in the compound (II). We then present a detailed DFT study based on B3LYP / 6-31G (d, p) geometric structures of compounds (I); (II) and another compound (III) also another asymmetric azine (Z) -2 - [(E) -2-benzylidenehydrazine-1-ylidene] -1,2-
\end{abstract}

diphenylethanone whose crystal structure is reported. The fundamental vibration wave numbers are calculated and a good agreement between the observed and calculated wave numbers is obtained. The study was extended to the HOMO-LUMO analysis to calculate the energy gap. The calculated HOMO and LUMO energy reveals that the charge is transferred into the molecule.

Keywords: Azines; crystal structures; DFT calculations, TD-DFT calculations 


\section{Introduction}

Azines and their derivatives constitute a polyvalent class of compounds in organic chemistry. They are the product of the condensation of an aldehyde or a ketone with hydrazine [1-3] and can be symmetrical and unsymmetrical. These compounds are considered to be analogues of 2,3diazabutadiene and commonly referred Schiff Bases because of the presence in their structures of the diiminic group $\mathrm{C}=\mathrm{N}-\mathrm{N}=\mathrm{C}$ [4-6]. A good number of symmetrical and unsymmetrical azines have largely contributed to the development of coordination chemistry acting as chelating agents having the design of new molecular materials with interesting physical properties [7-10]. They are known to find applications as nonlinear optical materials (NLO) [11-12]. Among the types of Schiff bases, polyazines are significantly used as nonlinear optical materials (NLO) because of their optical transparency [13]. They are of particular importance in the development of light-based technology for communication and computing [14]. These compounds have pharmacological and biological properties and close relationships with their structures, which act as anti-inflammatory, analgesic, antibacterial, antifungal, antitumor, anti-HIV and antimicrobial agents [15-19]. Azines are also important for drug design, organocatalysis and synthesis of heterocyclic compounds [2021] by undergoing different types of cyclo-addition reactions [21-22]. In recent years, computational studies on azines have been conducted to study their molecular properties, which involves the theoretical and experimental characterization of their electronic structure [23-26], including their conformational equilibrium structure, their tautomerism, their NMR spectra and potential energy distribution (PED) vibration frequencies [27-28]. The importance given to azine derivatives due to their wide application in various scientific fields was considered a research project in our laboratory [29-30]. Different methods of synthesis of symmetrical and unsymmetrical azines are reported [3,13,31] where the first cited are easily obtained, while their asymmetrical counterparts, they are it under harsher conditions [31,32-33]. These are prepared in two steps as described in the set of works reported in the literature, from two different aromatic derivatives aldehyde or ketone, and hydrazine hydrate [34-35] or selectively using hydrazine derivatives [3637]. In our case, we have drawn from the work reported in the literature [38] which indicates the possibility of preparing unsymmetrical azines in a single step by reacting two different carbonyl derivatives simultaneously with hydrazine sulfate in the presence of a base in molecular proportions: $1 / 1 / 1$, without worrying about the difference in reactivity between the $\mathrm{C}=\mathrm{O}$ groups. We then borrowed this new method which proves efficient and practical, on which we made a minor modification of the reaction conditions as indicated in the experimental part. We report in this paper the synthesis of two new unsymmetrical azines (compounds (I) and (II)) isolated with relatively 
good yields whose structures were characterized using FT-IR, UV-Vis and single-crystal X-ray diffraction techniques performed on single crystals on the one hand and a Density Functional Theory (DFT) calculations and Time-Dependent DFT (TDDFT) calculations are performed to get better insight into the geometrical and electronic properties, and to give a detailed description of structures spectroscopic assignments of the IR and UV-visible for the three unsymmetrical azines compound : I, II, III on the other hand, whose crystalline structure of the latter is reported [30]. The general structures of these compounds are given in scheme 1.

\section{Experimental Section}

\section{Materials and physical measurements}

Chemicals were purchased from commercial sources and unless specified, were used without further purification. Thin layer chromatography (TLC) was performed by using Merck silica gel (60 F254) plates $(0.25 \mathrm{~mm})$ and visualized under Ultraviolet light (UV). Melting points were determined with a digital melting point apparatus using capillary technique. Infrared (IR) spectra were recorded with a Shimadzu FTIR-8010M spectrometer between 400 and $4000 \mathrm{~cm}^{-1}(\mathrm{KBr}$ disks).UV-Vis measurements were obtained at room temperature using an UV-Vis 1800 UNICAM (version vision 32) spectrophotometer with standard quartz $(1 \mathrm{~cm})$ cells with DMSO solutions.

\subsection{X-ray crystallographic study}

X-ray single-crystal diffraction data were collected at $150^{\circ} \mathrm{K}$ for I-II and $293^{\circ} \mathrm{K}$ for III on a Bruker APEX II CCD diffractometer equipped with a graphite monochromator using Mo K $\alpha$ radiation $(\lambda=$

$0.71073 \AA$ ). The structures were solved by direct methods using the SIR2002 program [39] and refined on F2 by full matrix least-squares [40]. Unit cell refinement using all observed reflections and data reduction were performed using SAINT. All non hydrogen atoms were refined anisotropically and the hydrogen atoms were included in geometric positions. The final difference Fourier maps showed no peaks of chemical significance.

\subsection{Computational details}

Quantum mechanical calculations were used to carry out the optimized geometries and characterize the electronic and optical properties. All calculations were performed with the Gaussian09 program package [41].Density functional theory (DFT) and Time-Dependent DFT (TDDFT) were performed using the hybrid Becke's three parameters and Lee-Yang-Parr functional B3LYP [42-43] together with 6-31G(+)(d,p) basis sets [44] to investigate the ground and excited electronic states. 


\subsection{Synthesis}

\subsubsection{Synthesis of (E)-2-hydroxynaphtalene-1-carbaldehyde[(1E)-2-thienylmethylene]hydrazone}

(I)

To a stirred solution of 1eq of 2-hydroxy naphtalencarboxaldéhyde dissolved in $20 \mathrm{ml}$ DMSO (e.g. $(1.12 \mathrm{~g}, 0.01 \mathrm{~mol})$, hydrazine monohydrate (1eq $0.5 \mathrm{ml})$ was added. Then 2-thiophencarboxaldehyde $(0.92 \mathrm{ml}, 0.01 \mathrm{~mol})$ was also added. The solution was heated by refluxing the mixture for $2 \mathrm{~h}$ while controlling the reaction by TLC. At the end of the reaction and after cooling the reaction mixture, a brown precipitate is obtained which is filtered through Buchner and washed several times with cold DMSO (yield 69\%; m.p. $315^{\circ} \mathrm{C}$ ). The precipitate was recrystallized by slow evaporation in dimethylsulfoxide solution.

\subsubsection{Synthesis of (Z)-2-[(E)-2-(1-hydroxyphenyl)ethylidene-hydrazin-1-ylidene]-1,2-diphenylethanone} (II)

A mixture of benzyl $(2.10 \mathrm{~g}, 0.01 \mathrm{~mol})$ and hydrazine hydrate $(0.48 \mathrm{ml}, 0.01 \mathrm{~mol})$ in $50 \mathrm{ml}$ ethanol, we add 2-hydroxyacetophenone $1 \mathrm{ml}(0.01 \mathrm{~mol})$ and 2 drops of acetic acid (used as a catalyst) was refluxed for about $2 \mathrm{~h}$. The reaction was monitored by TLC until completion. The resulting yellow solid product was recrystallized from absolute ethanol to afford yellow prism of the title compound (yield $74 \%$; m.p. $153^{\circ} \mathrm{C}$ ).

\subsubsection{Synthesis of (Z)-2-[(E)-2-benzylidenehydrazin-1-ylidene]-1,2-diphenylethanone (III) [30]}

A mixture of benzaldehyde (1.06 g, $0.01 \mathrm{~mol})$, benzil (2.10 g; $0.01 \mathrm{~mol})$ and hydrazine hydrate $(0.32 \mathrm{~g}, 0.01 \mathrm{~mol})$ in $50 \mathrm{ml}$ of ethanol containing 2 drops of acetic acid was refluxed for about $2 \mathrm{~h}$. The reaction was monitored by TLC until completion. Excess solvent was evaporated under vacuum and the resulting yellow solid product was recrystallized from absolute ethanol to afford yellow needles of the title compound (yield $75 \%$; m.p. $144^{\circ} \mathrm{C}$ ). 


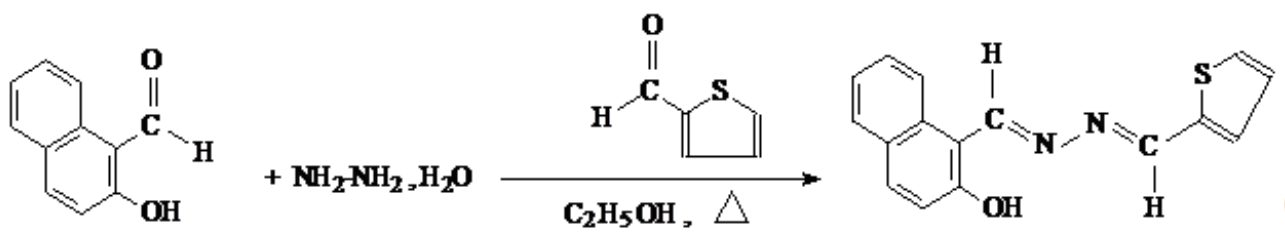

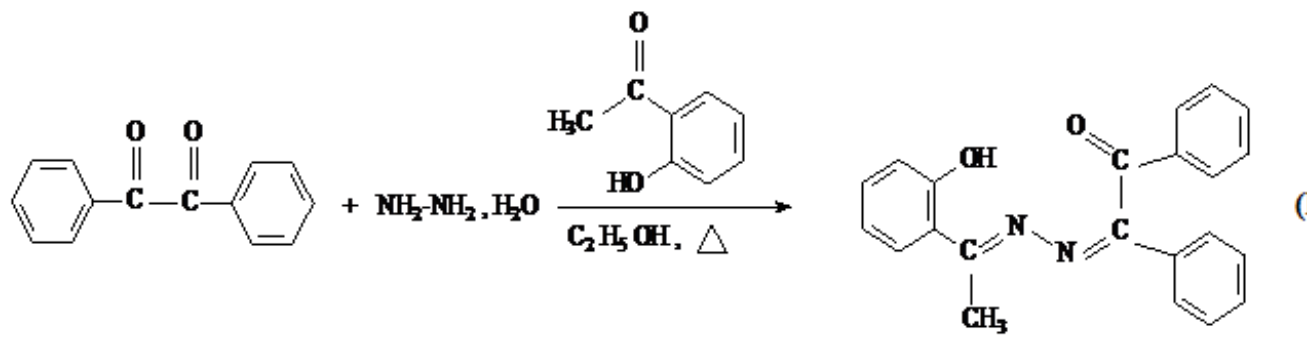

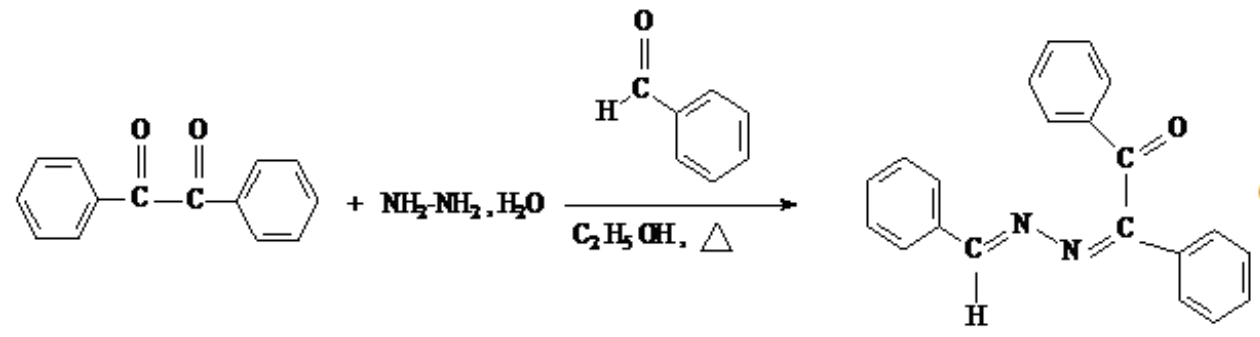

Scheme. 1 The synthesis schematic for I, II and III.

\section{Result and discussion}

\section{1. Crystallographic studies}

The crystals of molecules were grown in DMSO or ethanol solution through slow evaporation process and suitable crystals were collected and analyzed through single crystal X-rays diffraction analysis. The main crystal parameters are reported in Table 1. Some bond distances and angles are listed in Table 2. The numbering schema and a displacement ellipsoid plot of I, II and III are shown in Figure 1. (I) crystallized in a monoclinic system in $\mathrm{P} 2{ }_{1} / \mathrm{c}$ space group and with a four unit per cell $(\mathrm{Z}=4)$, (II) crystallized in a triclinic system in P-1 space group and with a two unit per cell $(\mathrm{Z}=2)$ and (III) crystallized in an orthorhombic system in Pnab space group and with eight unit per cell (Z $=8$ ). The asymmetric unit of both molecules (I and II) contains one independent molecule. The average bond lengths and bond angles parameters of ring systems (phenyl, thiophene and naphthalene) are in the normal ranges [45-47]. N-N (hydrazone) distances are in the range of typical single bond [1.398(6)-1.4077(16)] $\AA$ [48-50]. $\mathrm{C}=\mathrm{N}$ double bonds in hydrazone units are between [1.2893(19)-1.3014(18)] $\AA$. The torsion angles involving the $-\mathrm{N}=\mathrm{C}-$ units have values in the range of $\left[-171.02^{\circ}-179.90^{\circ}\right]$. All these data have similar values to previous structures [51-52]. The N13 
and N10 atoms in both molecules acts as potent acceptor for $\mathrm{O}_{\text {hydroxy }}-\mathrm{H} \cdots \mathrm{N}(1.805-1.715) \AA$

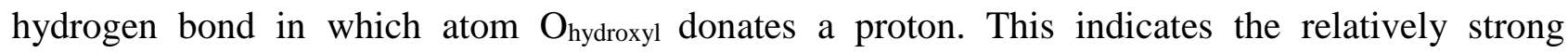
character of the intramolecular hydrogen bonding in these molecules [53].

The (I) molecular have an $\mathrm{E}$ conformation of the $\mathrm{C}=\mathrm{N}$ bonds and has near a planar structure, thiophene and naphthalene makes dihedral angles of $6.18^{\circ}$. Which, in addition to the observed bond distances, suggests partial delocalization of the $\pi$ electrons over the whole molecule. In the crystal structure, molecules of (I) are aligned head to foot along c axis, in columns parallel to [10 0 ] axis figure 2.There are no other significant intermolecular contacts.

The (II) molecular comprises a 1-acetophenone-2-benzylidenehydrazine backbone with an approximately orthogonal almost planar a phenyl ethanone substituent on atom C12. The phenyl ring of the acetophenone unit makes dihedral angles of 88.53(6) and 8.67(5), respectively, with the $\mathrm{C} 21-\mathrm{C} 22$ and $\mathrm{C} 13-\mathrm{C} 14$ phenyl rings. The dihedral angle between the two phenyl rings of the benzil unit is 88.68(6). The molecule adopt an E conformation with respect to the $\mathrm{C} 8=\mathrm{N} 10$ bond and an $\mathrm{Z}$ conformation with respect to the $\mathrm{C} 12=\mathrm{N} 11$ bond, with the carbonyl atom $\mathrm{O} 20$ and the $\mathrm{C} 13-\mathrm{C} 14$ phenyl ring. The molecular configuration is determined by the presence of two intramolecular bifurcated $\mathrm{O} 1-\mathrm{H} 1 \cdots \mathrm{N} 10$ and $\mathrm{C} 9-\mathrm{HA} 9 \cdots \mathrm{N} 11$ hydrogen bondsTable 3 . The first intramolecular hydrogen bond generate $S(6)$ ring motifs [54]. This six-membered pseudocycle is almost planar, the maximum deviation from the mean plane being $0.026 \AA$ for atom H1. In the crystal packing of II, molecules are stacked along the a-axis direction, forming a three-dimensional structure by $\mathrm{C}$ $\mathrm{H} . . \mathrm{O}$ intermolecular hydrogen bonds (Figure 3). In addition, theC $-\mathrm{H} \ldots \pi$ interaction involving the C21-C26 (centroid Cg) ring helps to stabilize the crystal structure (Figure 4).

Table 1. Crystallographic data and structure refinement details for (I and II)

\begin{tabular}{|c|c|c|}
\hline Compound & I & II \\
\hline Empirical formula & $\mathrm{C}_{16} \mathrm{H}_{12} \mathrm{~N}_{2} \mathrm{OS}$ & $\mathrm{C}_{22} \mathrm{H}_{18} \mathrm{~N}_{2} \mathrm{O}_{2}$ \\
\hline Formula weight, g/mol & 280.34 & 342.38 \\
\hline Crystal description & Prism & Prism \\
\hline Space group & $P 2_{1} 2_{1} 2_{1}$ & $P 2{ }_{1} / c$ \\
\hline Crystal system & Orthorhombic & Monoclinic \\
\hline $\mathrm{F}(000)$ & 584 & 720 \\
\hline & Unit cell dimensions \\
\hline
\end{tabular}




\begin{tabular}{|c|c|c|}
\hline $\mathrm{a} / \AA$ & $6.3030(7)$ & $17.8639(11)$ \\
\hline $\mathrm{b} / \AA$ & $12.3028(11)$ & $8.7124(6)$ \\
\hline $\mathrm{c} / \AA$ & $17.2381(15)$ & $11.5578(7)$ \\
\hline$\alpha /^{\circ}$ & 90 & 90 \\
\hline$\beta /^{\circ}$ & 90 & $104.782(3)$ \\
\hline$\gamma /{ }^{\circ}$ & 90 & 90 \\
\hline $\mathrm{V} / \AA^{3}$ & $1336.7(2)$ & $1739.29(19)$ \\
\hline $\mathrm{Z}$ & 4 & 4 \\
\hline Temperature/K & 150 & 150 \\
\hline $\begin{array}{l}\theta \text { Range for data } \\
\text { collection }\left(^{\circ}\right)\end{array}$ & $2.9-24.1$ & $2.4-26.8$ \\
\hline Radiation & Mo $\mathrm{K} \alpha(\lambda=0.71073)$ & Mo $\mathrm{K} \alpha(\lambda=0.71073)$ \\
\hline Dcalcd $\left(\mathrm{g} / \mathrm{cm}^{-3}\right)$ & 1.393 & 1.308 \\
\hline$\mu\left(\mathrm{mm}^{-1}\right)$ & 0.24 & 0.09 \\
\hline Range/indices (h, k, l) & $\begin{array}{c}-7 \leq \mathrm{h} \leq 8 \\
-9 \leq \mathrm{k} \leq 15 \\
-14 \leq 1 \leq 22\end{array}$ & $\begin{array}{r}-23 \leq \mathrm{h} \leq 16 \\
-11 \leq \mathrm{k} \leq 10 \\
-11 \leq 1 \leq 15\end{array}$ \\
\hline $\begin{array}{c}\text { Ref Nmb of reflections } \\
\text { measured }\end{array}$ & 7948 & 11628 \\
\hline $\begin{array}{l}\text { Number of independent } \\
\text { reflections }\end{array}$ & 3002 & 3954 \\
\hline Reflections with I > $2 \sigma(\mathrm{I})$ & 2073 & 2795 \\
\hline Number of parameters & 184 & 239 \\
\hline Refinement method & $\begin{array}{c}\text { Full-matrix } \\
\text { least-squares on F2 }\end{array}$ & $\begin{array}{c}\text { Full-matrix } \\
\text { least-squares on F2 }\end{array}$ \\
\hline Goodness-of-fit (GOF) & 1.013 & 1.019 \\
\hline $\mathrm{R}[\mathrm{F} 2>2 \sigma(\mathrm{F} 2)]$ & 0.059 & 0.04482 \\
\hline$w R(F 2)$ & 0.158 & 0.113 \\
\hline Rint & 0.050 & 0.034 \\
\hline
\end{tabular}




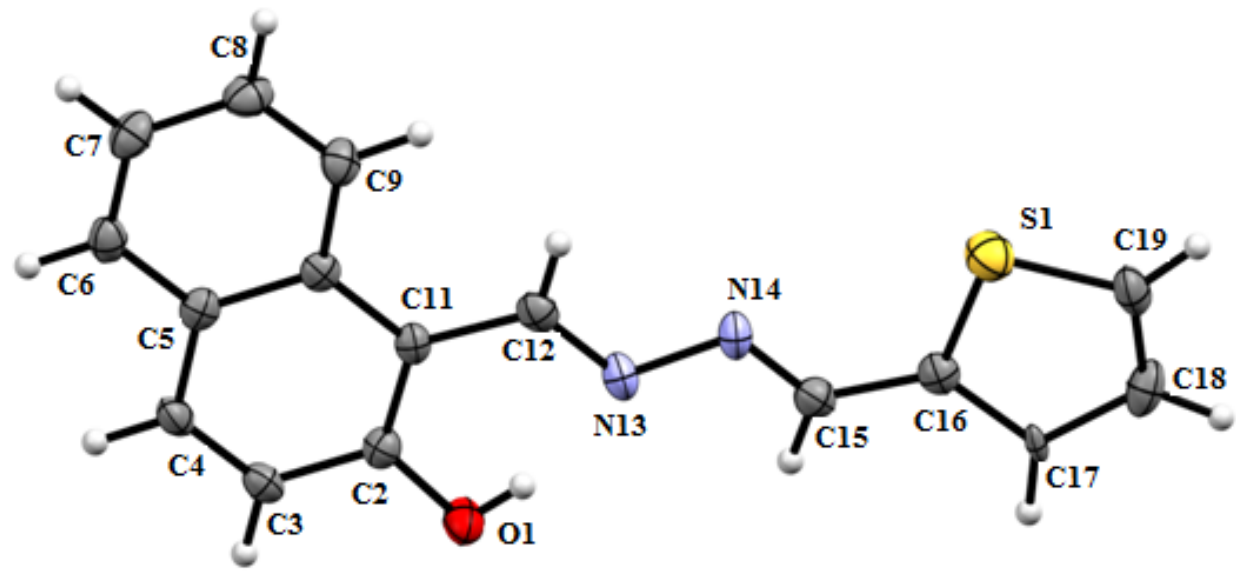

(I)

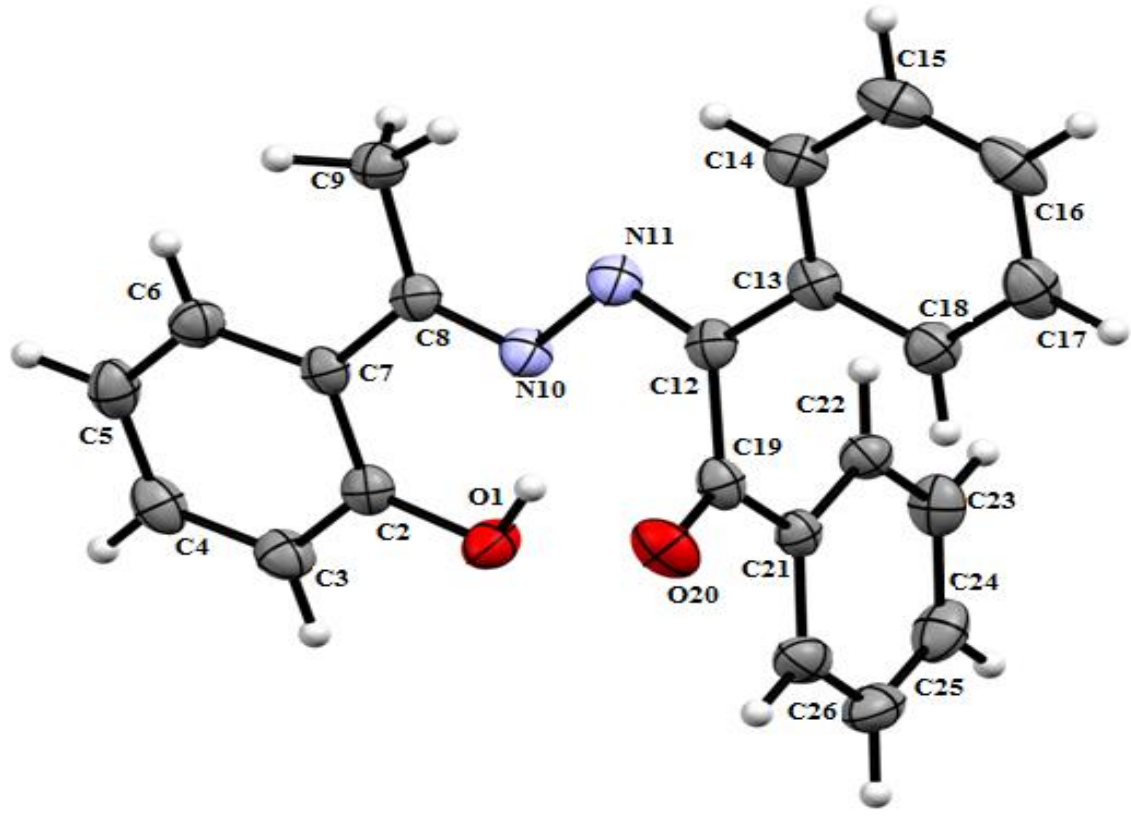

(II) 


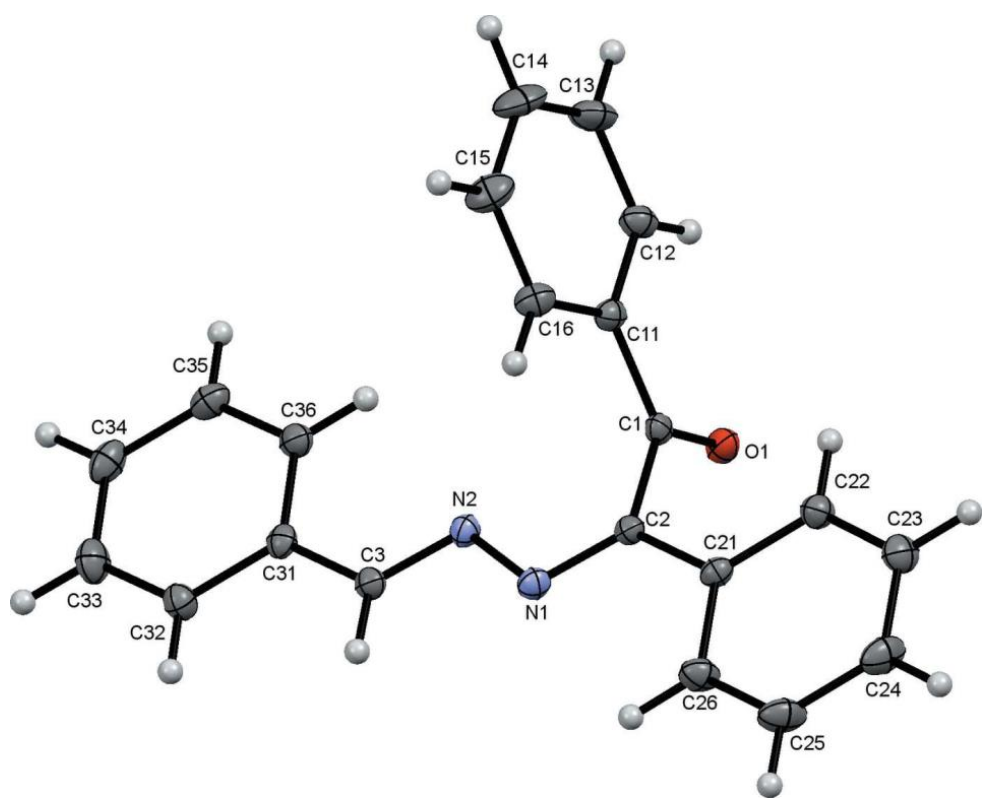

(III)

Figure 1.View of the molecular structure of I, II and III with the atom labeling.

Table 2. Some selected bond distances $(\AA)$ and angles $\left(^{\circ}\right)$ for ligands.

\begin{tabular}{|l|l|l|l|}
\hline Bond & Bnd lengths $(\stackrel{\AA}{\mathrm{A}})$ & Bond Angle & \\
\hline I & $1.348(6)$ & C2-O1-H1 & \\
\hline O1-C2 & $1.456(7)$ & O1-C2-C11 & $101(5)$ \\
C12-N13 & $1.292(6)$ & C2-C11-C12 & $122.4(5)$ \\
N13-N14 & $1.398(6)$ & N13-C12-C11 & $120.3(4)$ \\
N14-C15 & $1.294(7)$ & C12-N13-N14 & $120.6(4)$ \\
C15-C16 & $1.428(7)$ & C15-N14-N13 & $113.6(4)$ \\
C16-S1 & $1.708(5)$ & N14-C15-C16 & $111.6(4)$ \\
C19-S1 & $1.679(6)$ & C15-C16-S1 & $121.6(4)$ \\
\hline II & & $122.0(4)$ \\
\hline
\end{tabular}




\begin{tabular}{|l|l|l|l|}
\hline O1-C2 & $1.3536(18)$ & C2-O1-H1 & $104.1(11)$ \\
C7-C8 & $1.473(2)$ & O1-C2-C7 & $122.41(13)$ \\
C8-N10 & $1.3014(18)$ & C2-C7-C8 & $121.54(13)$ \\
N10-N11 & $1.4077(16)$ & N10-C8-C7 & $116.78(13)$ \\
N11-C12 & $1.2893(19)$ & C8-N10-N11 & $116.15(12)$ \\
C12-C13 & $1.475(2)$ & C12-N11-N10 & $112.20(12)$ \\
C12-C19 & $1.525(2)$ & N11-C12-C19 & $122.11(13)$ \\
C19-O20 & $1.2185(17)$ & O20-C19-C12 & $118.83(13)$ \\
\hline
\end{tabular}

Table 3. Distances $(\AA)$ and angles $\left(^{\circ}\right)$ of hydrogen bond for I and II.

\begin{tabular}{|c|c|c|c|c|}
\hline D-H...A & $\mathbf{d}(\mathrm{D}-\mathrm{H})$ & $d(H \ldots A)$ & $\mathbf{d}(\mathbf{D}-\mathbf{A})$ & D-H-A \\
\hline \multicolumn{5}{|c|}{$\mathbf{I}$} \\
\hline O1-H1 ... O13 & $0.78(7)$ & $1.81(6)$ & $2.552(6)$ & $159(6)$ \\
\hline \multicolumn{5}{|c|}{ II } \\
\hline $\mathrm{O} 1-\mathrm{H} 1 \ldots \mathrm{N} 10$ & $0.91(2)$ & $1.72(2)$ & $2.5529(17)$ & $152.6(16)$ \\
\hline C9-H9A...N11 & 0.9800 & 2.3200 & $2.765(2)$ & 107.00 \\
\hline $\mathrm{C} 4-\mathrm{H} 4 \ldots \mathrm{O} 1$ & 0.98500 & 2.4600 & $3.387(2)$ & 164.00 \\
\hline C5-H5...O1 & 0.9500 & 2.5700 & $3.253(19)$ & 129.00 \\
\hline
\end{tabular}




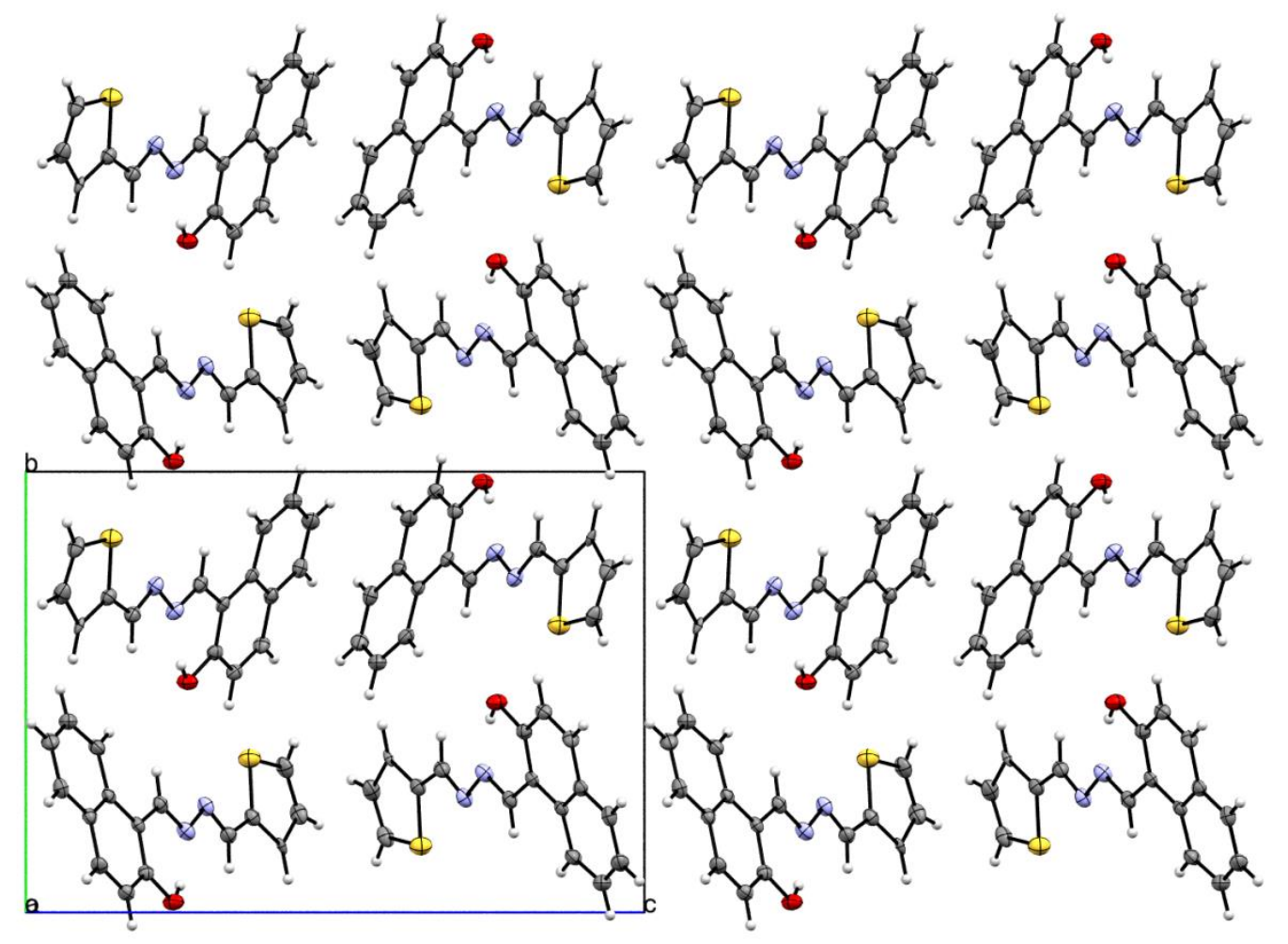

(a)

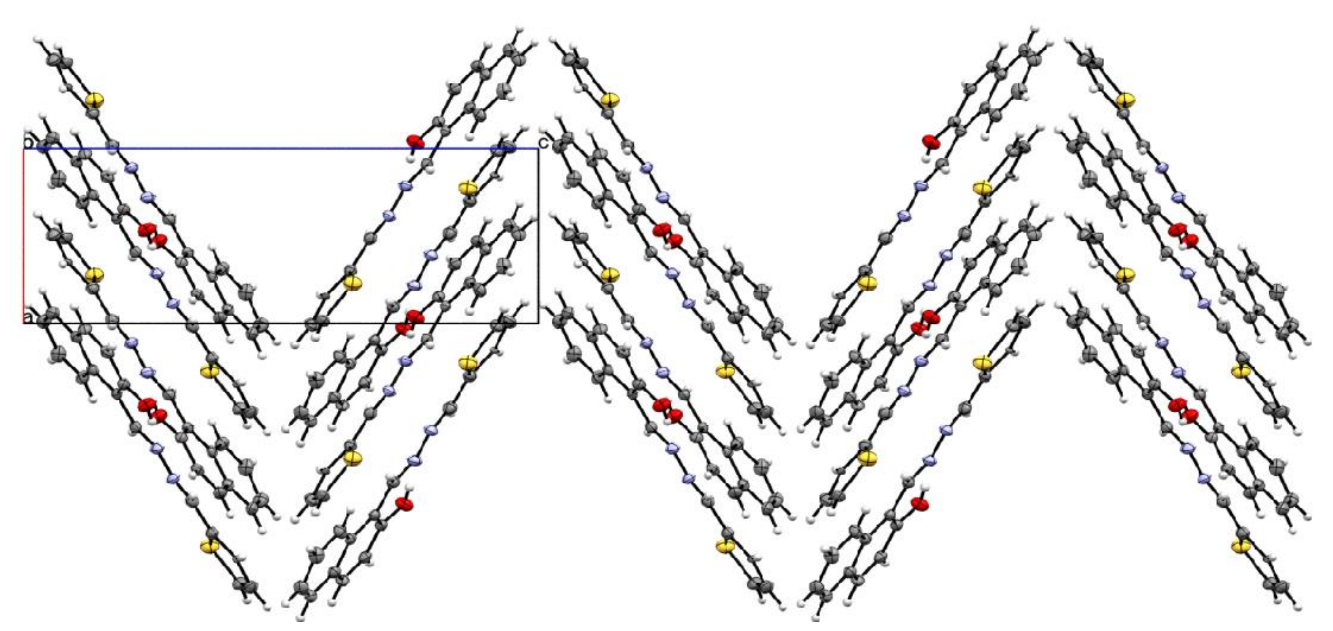

(b)

Figure 2. Cell packing for $\mathbf{I}$. (a) along the axis a, (b) along the axis b. 


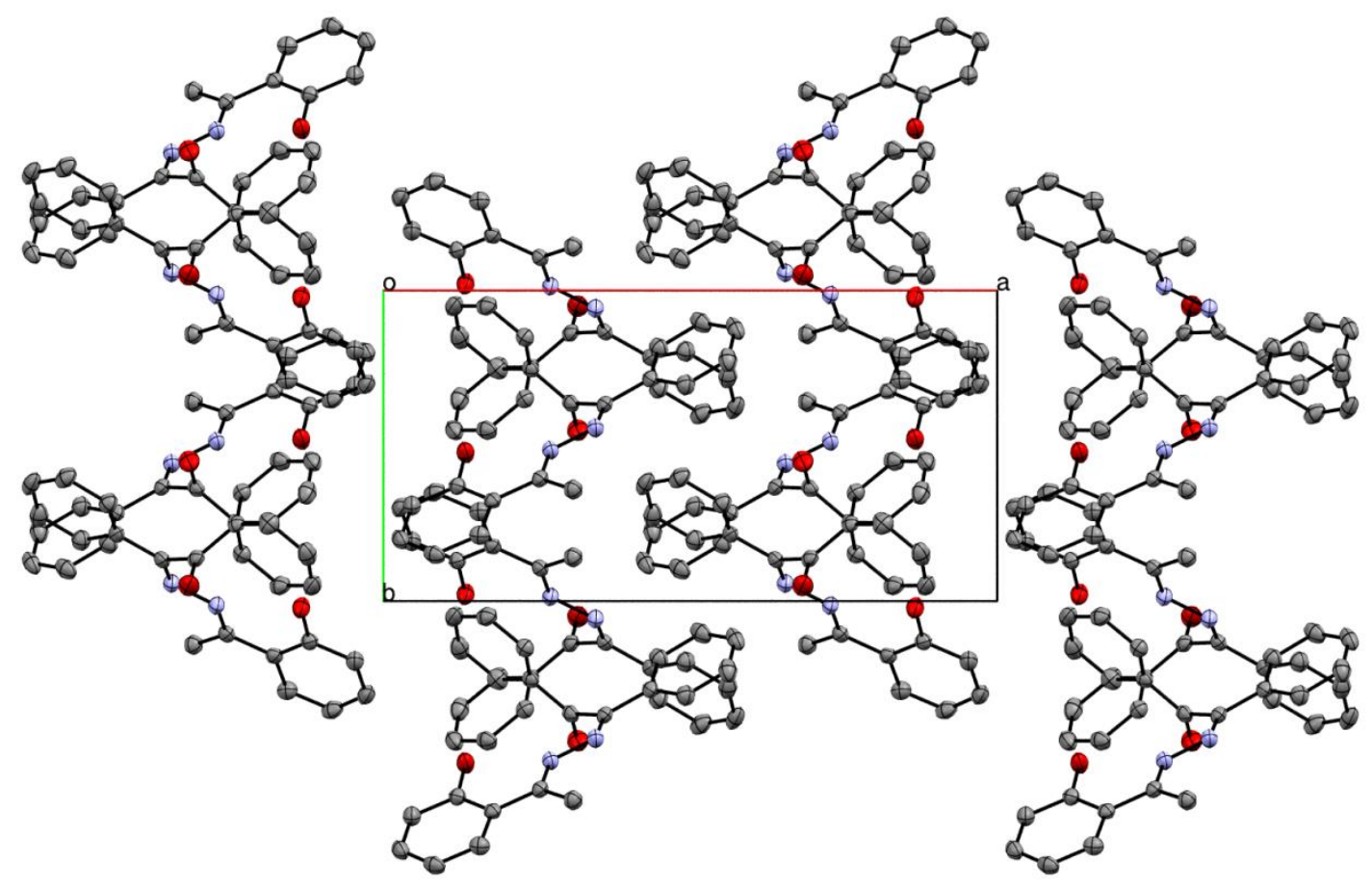

Figure 3. Cell packing for II.

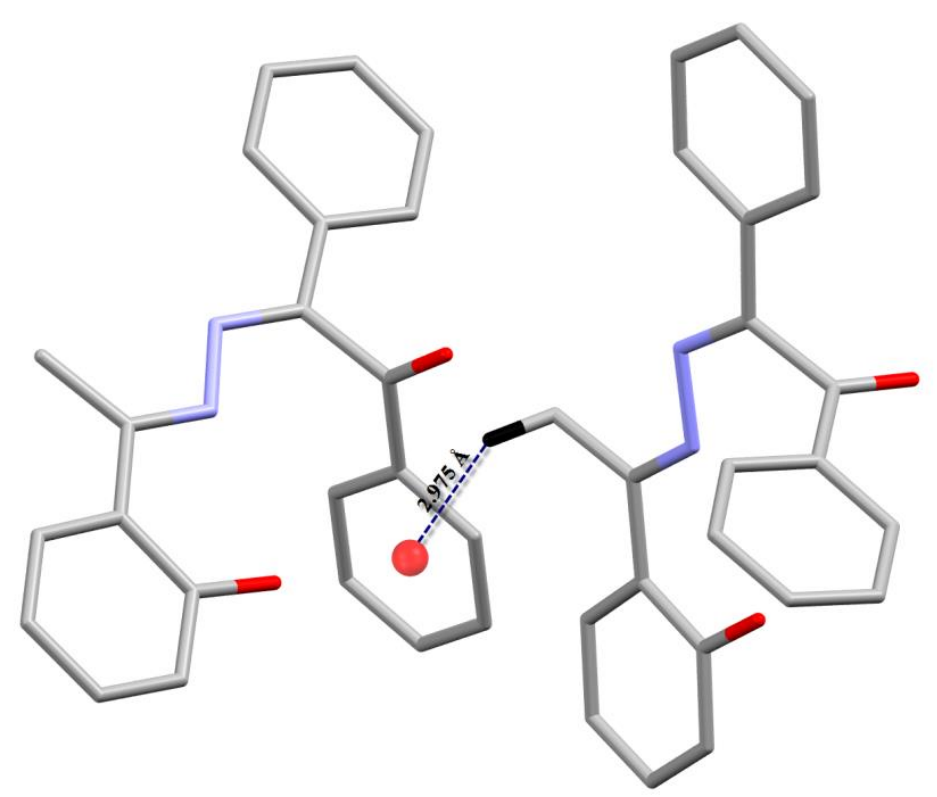

Figure 4. Cell packing for II. 


\subsection{IR Spectra Analyses}

The infrared spectra of ligands were analyzed in the region $4000-500 \mathrm{~cm}^{-1}$. Spectra shows a band at 3447 and $2888 \mathrm{~cm}^{-1}$ [55] assigned to intermolecular hydrogen bonded $\mathrm{v}(\mathrm{OH})$ for I and II respectively. The bands appearing around $1600 \mathrm{~cm}^{-1}$ are assigned to the $v(\mathrm{C}=\mathrm{N})[56,57]$. However, the absorption bands appearing at 1183 and $1175 \mathrm{~cm}^{-1}$ are assigned to the $v(\mathrm{~N}-\mathrm{N})$ [58,59] stretching for three compounds. The bands due to carbonyl $v(\mathrm{C}=\mathrm{O})$ were found at $1674 \mathrm{~cm}^{-1}$ for II and III [60].

\section{3. UV/Vis Studies}

The electronic spectra of the ligands were recorded in DMSO solutions, at room temperature and recorded in the region of $800-200 \mathrm{~nm}$. In the spectrum of the ligand I, four absorption bands were observed. The two first bands arising at 262 and $340 \mathrm{~nm}$ are attributable to $\pi \rightarrow \pi^{*}$ electronic transitions associated with the naphthalene unit [61-63]. The third absorption band located at 395 $\mathrm{nm}$ is attributed to $\mathrm{n} \rightarrow \pi^{*}$ transitions of conjugation between the lone pair of electrons and the conjugated bond of the aromatic cycle [61]. The presence of bands above $400 \mathrm{~nm}$ such as those at 410 pointed out the existence of a keto-amine tautomer of the ligand [54, 64, 65]. In the spectrum of the II ligand, the bands at 365 and 305nm were assigned to the imine group and the phenyl ring $\mathrm{n} \rightarrow \pi^{*}$ and $\pi \rightarrow \pi^{*}$ transitions. The transitions observed were consistent with those reported in the literature[66,67].

The electronic absorption spectrum of the III hydrazone ligand exhibits intense bands centered at 267 and $309 \mathrm{~nm}$. The intense band in high-energy region of the spectrum $(267 \mathrm{~nm})$ is related to $\boldsymbol{\pi} \rightarrow \boldsymbol{\pi}^{*}$ transitions of phenyl rings [68]. The other band can be assigned to $\boldsymbol{\pi} \rightarrow \boldsymbol{\pi}^{*}$ transitions associated with azomethine $(\mathrm{N}=\mathrm{C})$ chromophore.

\section{4. Optimized geometry}

The structure of I, II and III have been optimized at DFT/B3LYP level and the calculated bond lengths and angles are presented in Table 4 together with X-ray diffraction data. The calculated N-N bond lengths are smaller by $0.018,0.024$ and $0.023 \AA$ for I, II and II respectively, while the C-N bond distances are longer within $0.003-0.01 \AA$ than the experimental values. The calculated bond angles for the three compounds are generally in good agreement with the experimental ones as deviations do not exceed $0.02^{\circ}-4.56^{\circ}$. 
Table 4.Calculated bond lengths $(\AA)$ and angles $\left(^{\circ}\right)$ for (I-II-II).Experimental data are given in parentheses (in bold).

\begin{tabular}{|l|l|l|ll|}
\hline Bond lengths $(\mathbf{A})$ & \multicolumn{1}{|c|}{ I } & II & III & \\
\hline $\mathbf{C}=\mathbf{N}$ & $1.292(\mathbf{1 . 2 9 2})$ & $1.292 \mathbf{( 1 . 2 8 9 )}$ & $1.293 \quad \mathbf{( 1 . 2 8 8 )}$ \\
\hline $\mathbf{N}-\mathbf{N}$ & $1.380 \mathbf{( 1 . 3 9 8 )}$ & $1.383(\mathbf{1 . 4 0 7})$ & $1.391 \quad \mathbf{( 1 . 4 1 4 )}$ \\
\hline $\mathbf{C}-\mathbf{N}$ & $1.303(\mathbf{1 . 2 9 3})$ & $1.308 \mathbf{( 1 . 3 0 1 )}$ & $1.288 \quad \mathbf{( 1 . 2 7 6 )}$ \\
\hline Angles $\left.\mathbf{(}^{\mathbf{0}}\right)$ & & & & \\
\hline $\mathbf{N}=\mathbf{C}-\mathbf{C}$ & $122.61(\mathbf{1 2 1 . 5 5})$ & $119.39(\mathbf{1 1 6 . 7 7})$ & $119.66(\mathbf{1 2 0 . 2 5})$ \\
\hline $\mathbf{C}=\mathbf{N}-\mathbf{N}$ & $113.53 \mathbf{( 1 1 3 . 6 2 )}$ & $116.75(\mathbf{1 1 2 . 1 9})$ & $112.41(\mathbf{1 1 1 . 2 7})$ \\
\hline
\end{tabular}

\section{Infrared spectra}

Experimental IR spectra of I, II and III are shown in figure S1 (in Supplementary Material) while a rigorous analysis of vibrational modes is given in Table 5. The vibrational frequencies computed for the molecule in the gas phase were multiplied by the scaling factor of 0.960 as recommended in literature when calculations are performed at B3LYP/6-31G $(+)(\mathrm{d}, \mathrm{p})$ level. The calculated values are globally in good agreement with experimental data. The frequency for carbonyl $v(C=O)$ stretching has been calculated at $1321 \mathrm{~cm}^{-1}, 1667 \mathrm{~cm}^{-1}$ and $1648 \mathrm{~cm}^{-1}$ for I, II and III respectively in good agreement with experimental values. The experimental data of the $v(\mathrm{C}=\mathrm{N})$ stretching vibration appear at $1603 \mathrm{~cm}^{-1}$ for I, $1606 \mathrm{~cm}^{-1}$ for II and III, these bonds were calculated at $1638 \mathrm{~cm}^{-1}$ for I, $1618 \mathrm{~cm}^{-1}$ II and $1623 \mathrm{~cm}^{-1}$ for III. The experimental $\mathrm{v}(\mathrm{N}-\mathrm{N})$ stretching vibration appears at $1183 \mathrm{~cm}^{-}$ ${ }^{1}$ for I and $1175 \mathrm{~cm}^{-1}$ for II and III and is well reproduced by the calculated values of 1105, 1161, and $1119 \mathrm{~cm}^{-1}$ for I, II and III. The experimental band at $1420 \mathrm{~cm}^{-1}$ for I assigned to $\mathrm{v}(\mathrm{OH})$ ring from the phenolic group is calculated at $1407 \mathrm{~cm}^{-1}$. The high frequency region above $3051 \mathrm{~cm}^{-1}$ for I and $3053 \mathrm{~cm}^{-1}$ for II and III is the characteristic region for identification of $\mathrm{v}(\mathrm{CH})$ from aromatic phenyl group while these bonds were computed at $3161 \mathrm{~cm}^{-1}$ for I, $3183 \mathrm{~cm}^{-1}$ for II and $3172 \mathrm{~cm}^{-1}$ for III. 
Table 5. Calculated and experimental (given in parentheses) vibrational frequencies $\left(\mathrm{cm}^{-1}\right)$ for I, II and III.

\begin{tabular}{|c|c|c|c|}
\hline Assignement $\left(\mathrm{Cm}^{-1}\right)$ & I & II & III \\
\hline$v(\mathrm{O}-\mathrm{H})($ stretching $)$ & $1407 \quad(\mathbf{1 4 2 0})$ & - & - \\
\hline$v(\mathrm{C}=\mathrm{O}) \quad$ (stretching) & 1321 (1314) & 1667 (1674) & 1648 (1674) \\
\hline$v(\mathrm{C}=\mathrm{N})($ stretching $)$ & $1638 \quad(\mathbf{1 6 0 3})$ & $1618 \quad$ (1606) & 1623 (1606) \\
\hline $\mathrm{v}(\mathrm{C}-\mathrm{H}) \operatorname{ar}$ (stretching) & $3161 \quad$ (3051) & $3183 \quad(\mathbf{3 0 5 3})$ & $3178 \quad(\mathbf{3 0 5 3})$ \\
\hline$v(\mathrm{~N}-\mathrm{N})($ stretching$)$ & 1105 (1183) & 1161 (1175) & 1119 (1175) \\
\hline
\end{tabular}

\section{Electronic absorption spectra}

The calculated UV-visible absorption spectra of I, II and III are in good agreement with experimental results (see figure S2 in Supplementary Material). For I, four absorption features in the UV-visible region have been assigned to the experimental data (Table 6). The absorption wavelength in band (I) calculated at $255 \mathrm{~nm}$ and attributed to HOMO-2 $\rightarrow$ LUMO with $\pi-\pi^{*}$ character (Figure 5) can be assigned to the experimental band at $262 \mathrm{~nm}$. The calculated band (II) at $340 \mathrm{~nm}$ corresponds to a HOMO- $1 \rightarrow$ LUMO transition character and is attributed to an intra transfer $\pi-\pi^{*}$, they are likely corresponds to the experimental band measured at $340 \mathrm{~nm}$. The band (III) and (IV) calculated at $351 \mathrm{~nm}$ and $409 \mathrm{~nm}$ and originated from HOMO-3/HOMO $\rightarrow$ LUMO transitions respectively with a $\pi-\pi^{*}$ character on $\mathrm{C}=\mathrm{C}$ ring (band III) and $\mathrm{n}-\pi^{*}$ character from the azomethine $(\mathrm{C}=\mathrm{N})$ ring (band IV). For II, the experimental band measured at $234 \mathrm{~nm}$ and $305 \mathrm{~nm}$ are calculated at $233 \mathrm{~nm}$ and $316 \mathrm{~nm}$ and are attributed to HOMO-2 $\rightarrow$ LUMO+4/LUMO transitions originating from $n-\pi^{*}$ band (I) and $\pi-\pi^{*}$ from band (II). For III, peaks calculated at 267 and $328 \mathrm{~nm}$ and involved mainly HOMO-5 $\rightarrow$ LUMO+1 and HOMO $\rightarrow$ LUMO transition with an inter ligand charge transfer $\pi-\pi^{*}$ are likely correspond to the experimental bands measured at 267 and $309 \mathrm{~nm}$. 

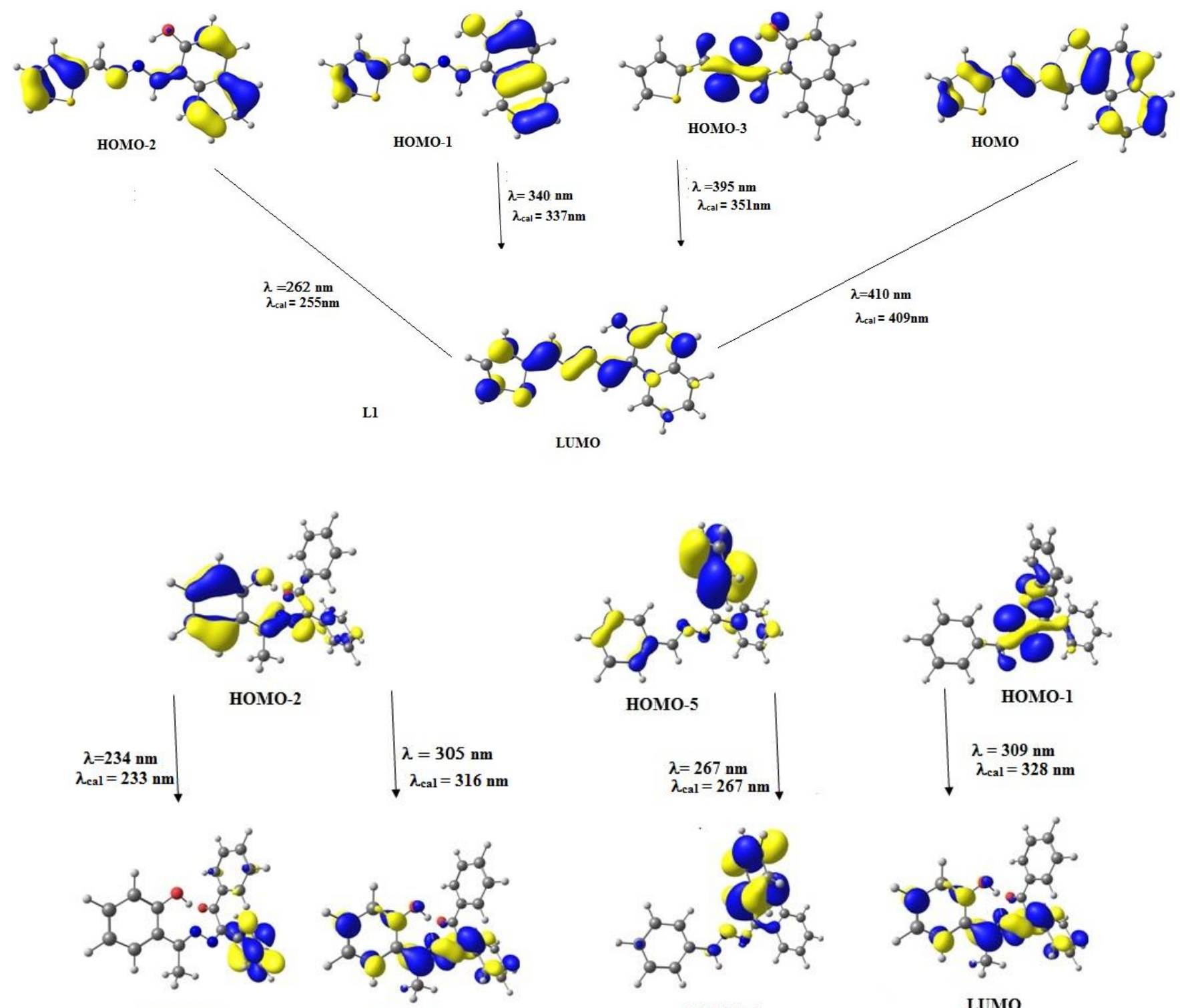

L2
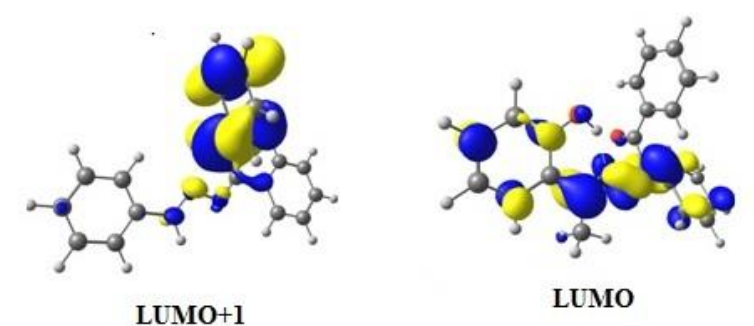

L3

Figure 5. Isodensity plots of selected molecular orbitals of I, II and III. 
Table 6. TD-DFT calculated excitations and assignments for I, II and III.

\begin{tabular}{|c|c|c|c|c|}
\hline & Wavelength(nm) & $\begin{array}{l}\text { Oscillator } \\
\text { Strength }(f)\end{array}$ & $\begin{array}{c}\text { Major } \\
\text { contribution }\end{array}$ & $\begin{array}{c}\text { Expwavelength } \\
\text { (nm) }\end{array}$ \\
\hline \multicolumn{5}{|c|}{ I } \\
\hline Band I & 255 & 0.040 & $\begin{array}{l}\mathrm{H}-2 \rightarrow \mathrm{L} \\
(56.49 \%)\end{array}$ & 262 \\
\hline Band II & 337 & 0.148 & $\begin{array}{l}\mathrm{H}-1 \rightarrow \mathrm{L} \\
(86.76 \%)\end{array}$ & 340 \\
\hline Band III & 351 & 0.002 & $\begin{array}{c}\mathrm{H}-3 \rightarrow \mathrm{L} \\
(98 \%)\end{array}$ & 395 \\
\hline Band IV & 409 & 0.764 & $\begin{array}{c}\mathrm{H} \rightarrow \mathrm{L} \\
(98.14 \%)\end{array}$ & 410 \\
\hline \multicolumn{5}{|c|}{ II } \\
\hline Band I & 233 & 0.0339 & $\begin{array}{c}\mathrm{H}-2 \rightarrow \mathrm{L}+4 \\
(79.12 \%)\end{array}$ & 234 \\
\hline Band II & 316 & 0.4968 & $\begin{array}{l}\mathrm{H}-2 \rightarrow \mathrm{L} \\
(58.64 \%)\end{array}$ & 305 \\
\hline \multicolumn{5}{|c|}{ III } \\
\hline Band I & 267 & 0.015 & $\begin{array}{c}\mathrm{H}-5 \rightarrow \mathrm{L}+1 \\
(54.18 \%)\end{array}$ & 267 \\
\hline Band II & 328 & 0.885 & $\begin{array}{l}\mathrm{H} \rightarrow \mathrm{L} \\
(56.1 \%)\end{array}$ & 309 \\
\hline
\end{tabular}




\section{Conclusion}

In the present work, we have reported the synthesis of three new hydrazone : (E)-2hydroxynaphtalene-1-carbaldehyde[(1E)-2-thienylmethylene $]$ hydrazone $\quad(I), \quad(Z)-2-[(E)-2-(1-$ hydroxyphenyl)ethylidene-hydrazin-1-ylidene]-1,2-diphenylEthanone (II) and (Z)-2-[(E)-2benzylidenehydrazin-1-ylidene]-1,2-diphenylethanone (III) with good yields. Their structures were established through UV-Vis, FT-IR spectral data and X-ray analysis. A theoretical study at DFT/B3LYP level for the three new compounds have furnished structural parameters, IR spectra, and UV-vis absorption in excellent agreement with the experimental data.

\section{Supplementary Materials:}

Figure S1: Simulated versus experimental infrared spectra of the I, II and III.

Figure S2: Experimental and simulated electronic absorption spectra of I

I, II and III.

Crystallographic Information File (CIF) for I and II.

\section{Compliance with ethical standards}

\section{Conflict of interest}

The authors declare that they have no conflict of interest.

\section{Acknowledgements}

The authors acknowledge the Algerian Ministry of Higher Education and Scientific Research, the Algerian Directorate General for Scientific Research and Technological Development, and Ferhat Abbas Sétif 1 University for financial support. Pr Lahcéne Ouahab and Dr.Thierry Roisnel from the University of Rennes 1, France, are thanked for the data collection. 


\section{References}

[1] B. Singh and A. K.Srivastav, Anew route to bimetallic azine-bridged complexes: synthesis and characterization of mononuclear ( $\mathrm{Mn}, \mathrm{Co}, \mathrm{Ni}, \mathrm{Cu}, \mathrm{Zn})$, homobinuclear $(\mathrm{Zn}-\mathrm{Zn})$ and heterobinuclear (Mn-Zn, Co-Zn, Ni-Zn, Cu-Zn) azine-bridged complexes, Transition Met.Chem. 21(1996) 413-417.

[2] Z. Yu, Y. Duan, L. Cheng, Z. Han, Z. Zheng, H. Zhou, J. Wu and Y. Tian, Aggregation induced emission in the rotatable molecules: the essential role of molecular interaction, J. Mater. Chem. 22 (2012) 16927-16932.

[3] J. Safari and S. Gandomi-Ravandi, Structure, synthesis and application of azines: a historical perspective RSC Adv. 4 (2014) 46224-46249.

[4] P. W. Zheng, W. Wang, \& X. M. Duan, N,N'-Bis(4-chlorobenzylidene)hydrazine, Acta Cryst. E61 (2005) o3020-0302.

[5] E. C. Kesslen, \& W. B. Euler, Single Crystal X-ray Structures of 2-

Pyridinecarboxaldehydeazine and Biacetylazine: Implications of the Conjugation in Systems with Carbon-Nitrogen Double Bonds, Chem. Mater. 11 (1999) 336-340.

[6] J. A. Armstrong, J. C. Barnes, \& T. J. RWeakley,1,2-Bis(2-pyridylformimidoyl)hydrazine, Acta Cryst. C54 (1998) 1923-1925.

[7] a) S. Gopinathan, S. A. Pardhy, I. R. Unny and C. Gopinatha, Synthesis and characterisation of binuclear phosphite complexes of rhodium(I) with bridging azines Inorganica Chimica Acta, 169 (1990) 39-42. b) N. Kundu, P. B. Chatterjee, M. Chaudhury, \& E. R. T. A. Tiekink, binuclear iminodiacetato-copper(II) complex with the N,N'-bis(pyridin-4-ylmethylene)hydrazine ligand as spacer, Acta Cryst. E61 (2005) m1583-m1585.

[8] Z. Xu, L. K. Thompson, \& D. O. Miller, Dicopper(II) Complexes Bridged by Single N-N Bonds. Magnetic Exchange Dependence on the Rotation Angle between the Magnetic Planes. Inorg. Chem. 36 (1997) 3985-3995.

[9] P. Barbazan, R. Carballo, B. Covelo, C. Lodeiro, J. C. Lima, E. M. Vazquez-Lopez, Synthesis, Characterization, and Photophysical Properties of 2-Hydroxybenzaldehyde [(1E)-1-pyridin-2-ylethylidene]hydrazone and Its Rhenium(I) Complexes, Eur. J. Inorg. Chem. 17 (2008) 2713-2720. 
[10] a) A. Panday and B. Singh, Synthesis, Characterization and Mesomorphic Properties of Aromatic Acid Dimers Mol. Cryst. Liq. Cryst., 552 (2012), 123-133 b) M. Sutradhar, Armando J.L. Pombeiro, Coordination chemistry of non-oxido, oxido and dioxidovanadium (IV/V) complexes with azine fragment ligands, Coord. Chem. Rev. 265 (2014) 89-124.

[11] R. Glaser, N. Knotts, P. Yu, L. Li, M. Chandrasekhar, C. Martin and C. L. Barnes, Perfect polar stacking of parallel beloamphiphile layers. Synthesis, structure and solid-state optical properties of the unsymmetrical acetophenone azine DCA, Dalton Trans. 21 (2006) 2891-2899.

[12] S. Poojary, D. Sunil, D. Kekuda, S. Sreenivasa, Fluorescent aromatic symmetrical azines: Synthesis and appraisal of their photophysical and electrochemical properties Opt Mater. 85 (2018) $1-7$.

[13] H. S. Nalwa, A. Kakuta and A. Mukoh, Third-order nonlinear optical properties of processable polyazine thin films, J Appl Phys. 73 (1993) 4743-4745.

[14] A. Jarczyk-Jedryka, K. Bijak, D. Sek, M. Siwy, M. Filapek, G. Malecki, S. Kula, G. Lewinska, E. M. Nowak, J. Sanetra, H. Janeczek, K. Smolarek, S. Mackowski, E. Schab-Balcerzak, Unsymmetrical and symmetrical azines toward application in organic photovoltaic, Opt Mater. 39 ( 2014) 58-68.

[15] J. Lasri, M. A. Magda, N. E. Eltayeb, B. A. Babgi, Synthesis of symmetrical and asymmetrical azines from hydrazones and/or ferrocenecarboxaldehyde as potential antimicrobialantitumor agents, J. Mol. Struct. 1164 (2018) 1-8.

[16] J. Gómez, A. H. Klahn, M. Fuentealba, D. Sierra, C. Olea-Azar, J. D.Maya, M. E. Medina, Ferrocenyl and cyrhetrenyl azines containing a 5-nitroheterocyclic moiety: Synthesis, structural characterization, electrochemistry and evaluation as anti-Trypanosoma cruzi agents, J. Organo met. Chem 839 (2017) 108-115

[17] S. Bondock, H. Gieman, A. El-Shafei, Selective synthesis, structural studies and antitumor evaluation of some novel unsymmetrical 1-hetaryl-4-(2-chloroquinolin-3-yl)azines, J. Saudi Chem Soc. 20 (2016) 695-702.

[18] E. Viñuelas-Zahínos , F. Luna-Giles , P. Torres-García , A.B. Rodríguez , A. Bernalte-García, Effects of a derivative thiazoline/thiazolidine azine ligand and its cadmium complexes on phagocytic activity by human neutrophils, Inorg. Chim. Acta. 366 (2011) 373-379.

[19] a) R. Manikannan, R. Venkatesan, S. Muthusubramanian, P. Yogeeswari, D. Sriram, Pyrazole derivatives from azines of substituted phenacyl aryl/cyclohexylsulfides and their antimycobacterial activity, Bioorg Med Chem Lett 20 (2010) 6920-6924. b) I. Picón-Ferrer, F. Hueso-Ureña, N. A. 
Illán-Cabeza, S. B. Jiménez-Pulido, J. M. Martínez-Martos, M. J. Ramírez-Expósito, M. N. Moreno-Carretero, Chloro-fac-tricarbonylrhenium(I) complexes of asymmetric azines derived from 6-acetyl-1,3,7-trimethylpteridine-2,4(1H,3H)-dione with hydrazine and aromatic aldehydes: Preparation, structural characterization and biological activity against several human tumor cell lines, J Inorg Biochem. 103 (2009) 94-100.

[20] a) H. Hayashi, J. Somei, M. Akei, T. Suga, H. Kigami, N. Hiramatsu, H. Itoyama, T. Nakano T. Okazaki, Preparation of sulfonated resins as an immobilized phase-transfer catalyst for the hydrolysis of benzophenone azine to hydrazine, J. catal. 130 (1991) 547-555. b) Milan Potáček, Radek Marek, Zdirad Žák, Julie Trottier, Zdeněk JanoušekHeinz G.Viehe, Novel thermal tetracyclization by intramolecular azine "criss-cross" addition, Tetrahedron Lett. 34 (1993) 83418344. c) B. Krishnakumar, M. Swaminathan, An expeditious and solvent free synthesis of azine derivatives using sulfated anatase-titania as a novel solid acid catalyst

Catal. Commun. 16 (2011) 50-55.

[21] R. Grashey and A. Padwa, Azomethine Imines In 1,3-Dipolar Cycloaddition Chemistry, General Heterocycl Chem. 1 (1984) 733-814.

[22] T. Wagner-Jauregg, Reactions of azines and imines (azomethines, Schiff's bases) with dienophiles, Synthesis. 6 (1976) 349-373.

[23] M. Lewis, R. Glaser, The Azine Bridge as a Conjugation Stopper: An NMR Spectroscopic Study of Electron Delocalization in Acetophenone Azines Org. Chem. 67 (2002) 67 1441-1447.

[24] R. Glaser, M. Lewis, Z. Wu, Stereochemistry and Stereoelectronics of Azines. 13.

Conformational Effects on the Quadrupolarity of Azines. An Ab Initio Quantum-Mechanical Study of a Lateral Synthon, Mol. Model. 6 (2000) 86-98.

[25] R. Glaser, G. S. Chen, Asymmetrization effects on structures and populations of the ground state of dipolar donor-acceptor-substituted molecular organic NLO materials, J. Comput. Chem. 19 (1998) 1130-1140.

[26] V. A. Sauro, M. S. Workentin, Evaluation of the Extent of Conjugation in Symmetrical and Asymmetrical Aryl-Substituted Acetophenone Azines Using Electrochemical Methods, J. Org. Chem. 66 (2001) 831-838. 
[27] a) R. Arulmani, K.R. Sankaran, Synthesis, spectral, SHG efficiency and computational studies of some newly synthesized unsymmetrical azines of 4-biphenylcarboxaldehyde, Spectroc. Acta A: Molecular and Biomolecular Spectroscopy 129 (2014) 491-498. b) V.Arun and K.R.Sankaran, Characterization and Computational analysis of unsymmetrical azines, Can. J. Trans. 3 (3) ( 2015) 319-326.

[28] T. Karakurt, A. Cukurovali, N. Tuna Subasi, A. Onaran, A. Ece, S. Eker, I. Kani, Experimental and theoretical studies on tautomeric structures of a newly synthesized 2,2'(hydrazine-1,2diylidenebis(propan-1-yl-1-ylidene))diphenol, Chemical Physics Letters. 693 (2018) 132-145. [29] A. Bouchama, A. Bendaas, S. Bouacida, M. Yahiaoui, P. Benard-Rocherulle and A. Djedouani, (Z)-1,2-Diphenyl-2-(phenylhydrazono)ethanone, Acta Cryst. E63 (2007) o1990-o1992.

[30] A. Bouchama, M. Yahiaoui, C. Chiter, Z. Setifi and J. Simpson, Crystal structure of (Z)-2-[(E)2-benzylidenehydrazin-1-ylidene]-1,2-diphenylethanone, Acta Cryst. E71 (2015) 35-37.

[31] I. Timtcheva A. Pentchev,St. Metsov, Sn. Bakalova, V. Kolevab \& P. Nikolov "Unsymmetrical Azines of 4-Acetyl-3-Methyl-1-Phenyl-5-Pyrazolone. Spectral Characteristics and Structure, Dyes Pigm. 28 (2) (1995)131-138

[32] K. S. Singh, Y. A. Mozharivskyj, C. Thöne, M. R. Kollipara, New mononuclear ruthenium complexes of $\eta 5$-cyclichydrocarbon containing azine ligands: Syntheses, spectral and structural studies, J. Organomet. Chem. 690 (2005) 3720-3729.

[33] a) S-M. Chi, Y-F. Wang, X. Gan, D-H. Wang, W-F. Fu, Synthesis, structures, and spectroscopic properties of copper(I) complexes bearing 7-acetamido-4-methyl-1,8-naphthyridin-2carbaldehyde azine and 1,2-bis(diphenylphosphino) ethane ligands, Cent. Eur. J. Chem. 7(4) (2009) 923-928. b) B. An, R-M. Zhou, L. Sun, Y. Bai, D-B. Dang, Crystal structures and spectral properties of two polyoxometalate-based inorganic-organic compounds from silver-azine building blocks with bis-bidentate and tridentate ligands, Spectroc. Acta A : Molecular and Biomolecular Spectroscopy 128 (2014) 319-326.

[34] S-H. Kim, S-Y. Gwon, S.M. Burkinshawc, Y-A Son, The synthesis and proton-induced spectral switching of a novel azine dye and its boron complex, Dyes Pigm. 87 (2010) 268-271. 
[35] a) K. Karaoğlu, K. Serbest, M. Emirik, E. Sahin, An unsymmetrical ferrocene based azine and its $\mathrm{Cu}$ (II) complex: Spectroscopy, crystal structure, electrochemistry and DFT calculations, J. Organomet. Chem. 775 (2015) 80-87. b) G. Elmaci, E. Aktan, N. Seferoglu, T. Hökelek, Z. Seferoglu, Synthesis, molecular structure and computational study of (Z)-2-((E)-4nitrobenzylidene)hydrazone)-1,2-diphenylethan-1-one, J. Mol. Struct. 1099 (2015) 83-91.

[36] J. C. Justo de Pomar and J. A. Soderquist, Tetrahedron Lett. Unsymmetrical azines via triisopropylsilyl hydrazine, 41 (2000) 3285-3289.

[37] J. Galeta, S. Man, A. Valoušková, M. Potáček, Substituted homoallenyl aldehydes and their derivatives. Part 2: Azines, Chem. Pap. 67 (2013) 40-50.

[38] J. Safari, S. Gandomi-Ravandi, M. Monemi, Novel and selective synthesis of unsymmetrical azine derivatives via a mild reaction, Monatsh. Chem. 144 (2013) 1375-1380.

[39] M. C. Burla, R. Caliandro, M. Camalli, B. Carrozzini, G.L. Cascarano, L.DeCaro, C. Giacovazzo, G. Polidori, R. Spagna, J. Appl. Cryst. 38 (2005) 381-390.

[40] G.M. Sheldrick. SHELX97 - Program for Crystal Structure Analysis (Release 97 2), Göttingen (1998); (b) Bruker-AXS. SAINT and SADABS, Bruker Analytical X-ray Systems Inc., Madison, WI (2009).

[41] M.J. Frisch, G.W. Trucks, H.B. Schlegel, G.E. Scuseria, M.A.n Robb, J.R. Cheeseman, G. Scalmani, V. Barone, B. Mennucci, G.A. Petersson, H. Nakatsuji, M. Caricato, X. Li, H.P. Hratchian, A.F. Izmaylov, J. Bloino, G. Zheng, J.L. Sonnenberg, M. Hada, M. Ehara, K. Toyota, R. Fukuda, J. Hasegawa, M. Ishida, T. Nakajima, Y. Honda, O. Kitao, H. Nakai, T. Vreven, J.A. Montgomery, Jr, J.E. Peralta, F. Ogliaro, M. Bearpark, J.J. Heyd, E. Brothers, K.N. Kudin, V.N. Staroverov, R. Kobayashi, J. Normand, K. Raghavachari, A. Rendell, J.C. Burant, S.S. Iyengar, J. Tomasi, M. Cossi, N. Rega, J.M. Millam, M. Klene, J.E. Knox, J.B. Cross, V. Bakken, C. Adamo, J. Jaramillo, R. Gomperts, R.E. Stratmann, O. Yazyev, A.J. Austin, R. Cammi, C. Pomelli, J.W. Ochterski, R.L. Martin, K. Morokuma, V.G. Zakrzewski, G.A. Voth, P. Salvador, J.J. Dannenberg, S. Dapprich, A.D. Daniels, O. Farkas, J.B. Foresman, J.V. Ortiz, J. Cioslowski, D.J. Fox, Gaussian Inc, Wallingford, CT, (2009).

[42] A.D. Becke, Density-functional thermochemistry. III. The role of exact exchange, J. Chem. Phys. 98 (1993) 5648-5652.

[43] C. Lee, W. Yang, R.G. Parr,Development of the Colle-Salvetti correlation-energy formula into a functional of the electron density, Phys. Rev. B. 37 (1988)785-789. 
[44] G. A. Petersson, M. A. Al-Laham, A complete basis set model chemistry. II. Open-shell systems and the total energies of the first-row atoms, J. Chem. Phys. 94 (1991) 6081-6090.

[45] I. Warad, S. F. Haddad, M. Al-Noaimi, B. Hammoutid and T. Ben Hadda, N-[(E)-2Chlorobenzylidene]thiophene-2-carbohydrazide, Acta Cryst. E69 (2013) o1442.

[46] C. Glidewell, J. N. Low, J. M. S. Skakle and J. Wardell, Isomers and polymorphs of (E,E)-1,4bis(nitrophenyl)-2,3-diaza-1,3-butadienes, Acta Cryst. B62 (2006) 666-675.

[47] Y. Ishikawa and Y. Motohashi, (E)-6,8-Dichloro-3-\{[(naphthalen-1ylmethyl)iminiumyl]methyl\}-2H-chromen-4-olate, Acta Cryst. E69 (2013) o1226.

[48] X.-M. Duan, P.-W. Zheng and B. Zhou, N,N00-Bis(3-hydroxy-4-methoxybenzylidene)hydrazine, Acta Cryst E61 (2005) o3449-o3451.

[49] Q.-H. Wang, G.-C. Guo and M.-S. Wang, 1,4-Bis(4-dimethylaminobenzyl)-2,3-diaza-1,3butadiene Acta Cryst. E61(2005) o1156-o1157.

[50] P.-W. Zheng, Q.-M. Qiu, Y.-Y. Lin and K.-F. Liu, N,N00-Bis(2,6dichlorobenzylidene)hydrazine, Acta Cryst. E62 (2006) o1913-o1914.

[51] G. Elmacı, E. Aktan, N. Seferoğlu, T. Hökelek, Z. Seferoğlu, Synthesis, molecular structure and computational study of (Z)-2-((E)-4-nitrobenzylidene)hydrazone)-1,2-diphenylethan-1-one, J. Mol. Struct. 1099 (2015) 83-91.

[52] H. Tanak, Crystal Structure, Spectroscopy, and Quantum Chemical Studies of (E)-2-[(2Chlorophenyl)iminomethyl]-4-trifluoromethoxyphenol, J. Phys. Chem. A. 115(47) (2011) 1386513876.

[53] A. Abbasi, G. Mohammadi Ziarani, S. Tarighi, (Z)-2-[(E)-2-(1-Benzothiophen-3-ylmethylidene)hydrazin-1-ylidene]-1,2-diphenylethanone, Acta Cryst. E 3 (2007) o2579-o2580.

[54] A. Djedouani, S. Boufas, F. Cleymand, M. François and S. Fleutot, Crystal structure of (E)-4hydroxy-3-\{1-[(4-hydroxyphenyl)imino]ethyl\}-6-methyl-2H-pyran-2-one, Acta Cryst. E71 (2015) o564-0565

[55] M. El Amane, Y. Kennouche, M. M.EIM, Synthesis and characterization of Salicylaldazine and its mixed ligand complexes[ML( $\left.\left.\mathrm{H}_{2} \mathrm{O}\right)\right],\left[\mathrm{M}(\mathrm{LH})_{2}(\mathrm{caf}) \mathrm{n}\right], \mathrm{M}=\mathrm{Zn}^{2+}, \mathrm{Cd}^{2+}, \mathrm{Ni}^{2+}, \mathrm{Cu}^{2+}, \mathrm{Co}^{2+}$, $\mathrm{Mn}^{2+}, \mathrm{Fe}^{2+}, \mathrm{n}=1,2$, caf $=$ caffeine, Research Journal of Chemical Sciences, 4 (2014) 72-84. 
[56] S. Bondock, H. Gieman, A. El-Shafei, Selective synthesis, structur al studies and antitumor evaluation of some novel unsymmetrical 1-hetaryl-4-(2-chloroqu inolin-3-yl)azines, J Saudi Chem Soc. 20 (2016) 695-702.

[57] R. A. Nyquist, T. L. Peters and P. B. Budde, Infrared and Raman correlations of arylaldehyde azines : asymmetric and symmetric $(\mathrm{C}=\mathrm{N})_{2}$ stretching, Spectrochimica Acta. 34 (1977) 503-504. [58] M.M. Abo Aly. Infrared and Raman spectra of somesymmetric azines, Spectrochimica Acta Part A. 55 (1999) 1711-1714.

[59] R .Arulmani, K.R.Sankaran, Synthesis spectral, SHG efficiency and computational studies of some newly synthesized unsymmetrical azines of 4-biphenylcarboxaldehyde, Spectrochimica Acta Part A. : Molecular and Biomolecular Spectroscopy 129 (2014) 491-498.

[60] V.N. Patange, B.R. Arbad, V.G. Mane, S.D. Salunke, Synthesis, physico-chemical and antimicrobial screening studies of some transition metal complexes with O:O donor ligands, Transit Metal Chem 32 (2007) 944-949.

[61] A.M. Ajlouni, Z. Taha, K. Al-Hassan and A.M. Abu Anzeh, Synthesis, characterization, luminescence properties and antioxidant activity of $\operatorname{Ln}(\mathrm{III})$ complexes with a new aryl amide bridging ligand J. Lumin., 132 (2012) 1357-1363.

[62] Z.A. Taha, A.M. Ajlouni and W.A. Momani, Structural, luminescence and biological studies of trivalent lanthanide complexes with N,N'-bis(2-hydroxynaphthylmethylidene)-1,3propanediamine Schiff base ligand, J. Lum., 132 (2012) 2832-2841.

[63] H. Temel, S. Pasaa, Y.S. Ocak, I. Yilmaz, S. Demird and I. Ozdemird, Synthesis, characterization, electrochemical behaviors and applications in the Suzuki-Miyaura cross-coupling reactions of $\mathrm{N}_{2} \mathrm{~S}_{2} \mathrm{O}_{2}$ thio Schiff base ligand and its $\mathrm{Cu}(\mathrm{II}), \mathrm{Co}(\mathrm{III}), \mathrm{Ni}(\mathrm{II}), \mathrm{Pd}(\mathrm{II})$ complexes and their usage in the fabrication of organic-inorganic hybrid devices, Synthetic Metals, 161 (2012) 2765-2775.

[64] Ö. Güngör and P. Gürkan, Synthesis and spectroscopic properties of novel asymmetric Schiff bases, Spectrochim. Acta. A., 77 (2010) 304-311.

[65] H. Ünver, E. Kendi, K. Güvenand and T. Nuri Durlu, Synthesis, Spectroscopic Studies, Crystal Structure and Conformation Analysis of $\mathrm{N}$-(2-Fluoro-3-methoxy)-salicylaldimine Z Naturforsch, $57 b(2002) 685-690$. 
[66] M. Gülcan, M. Sönmez, I. Berber, Synthesis, characterization, and antimicrobial activity of a new pyrimidine Schiff base and its $\mathrm{Cu}(\mathrm{II}), \mathrm{Ni}(\mathrm{II}), \mathrm{Co}(\mathrm{II}), \mathrm{Pt}(\mathrm{II})$, and $\mathrm{Pd}(\mathrm{II})$ complexes, Turk. J. Chem. 36 (2012) 189-200.

[67] M. Sönmez, M.E. Hacıyusufoğlu, Synthesis, characterization of Co(II), Ni(II), Cu(II) and $\mathrm{Zn}(\mathrm{II})$ Schiff base and complexes derived from acetylacetone with 1-amino-5-beuzoyl-4-phenyl1H-pyrimidine-2one Asian J. Chem. 18 (2006) 2032-2036.

[68] A. Bottcher, T. Takeuchi, KI. Hardcastel, TJ. Meade, HB. Gray, Spectroscopy and Electrochemistry of Cobalt(III) Schiff Base Complexes, Inorg Chem. 36 (1997) 2498-2504. 